\title{
Valuation of ecosystem services to inform management of multiple-use landscapes
}

Shan Ma ${ }^{\mathrm{a}}$, Jennifer M. Duggan ${ }^{\mathrm{a}, \mathrm{b}, 1}$, Bradley A. Eichelberger ${ }^{\mathrm{a}}$, Brynn W. McNally ${ }^{\mathrm{a}}$, Jeffrey R. Foster ${ }^{\mathrm{c}}$, Eda Pepi ${ }^{\mathrm{d}}$, Marc N. Conte ${ }^{\mathrm{a}, 2}$, Gretchen C. Daily ${ }^{\mathrm{a}, \mathrm{e}}$, and Guy Ziv ${ }^{\mathrm{a}, 3,{ }^{*}}$

a. Natural Capital Project, Stanford University, 371 Serra Mall, Stanford, CA 94305-5020, USA.

b. School of Environmental and Forest Sciences, University of Washington, Box 352100, Seattle, WA 98195-2100, USA.

c. Public Works, Joint Base Lewis-McChord, Box 339500 MS17, WA 98433-9500, USA.

d. Department of Anthropology, Stanford University, 450 Serra Mall, Main Quadrangle Stanford, CA, 94305-2034, USA.

e. Center for Conservation Biology, Department of Biology, and Woods Institute for the Environment, Stanford University, 371 Serra Mall, Stanford, CA 94305-5020, USA.

*Corresponding author

Email addresses:

Shan Ma

Jennifer M. Duggan

Bradley A. Eichelberger

Brynn W. McNally

Jeffrey R. Foster

Eda Pepi

Marc N. Conte

Gretchen C. Daily

Guy Ziv mashan@stanford.edu

jduggan@csumb.edu

beichelb@stanford.edu

brynnmcnally@gmail.com

jeffrey.r.foster@us.army.mil

pepi@stanford.edu

mconte7@fordham.edu

gdaily@stanford.edu

g.ziv@leeds.ac.uk

\footnotetext{
${ }^{1}$ Present address: Division of Science and Environmental Policy, California State University Monterey Bay, 100 Campus Center, Seaside, CA 93955, USA.

${ }^{2}$ Present address: Department of Economics, Fordham University, 3 Washington Square, Larchmont, NY 10538, USA.

${ }^{3}$ Present address: School of Geography, University of Leeds, University Road, Leeds LS2 9JT, UK.
} 


\title{
Valuation of ecosystem services to inform management of multiple-use landscapes
}

\begin{abstract}
Public agencies worldwide are increasingly adopting an ecosystem service framework to manage lands serving multiple uses. Yet, reliable, practical, and well-tailored methods remain a major limitation in moving from conceptual to actionable approaches. Together with one of the largest federal land managing agencies, we co-develop and co-demonstrate an ecosystem services approach tailored to specific decisions, through a process with potentially widespread relevance. With the U.S. Department of Defense (DoD), we focus on balancing military training with biodiversity and resource conservation under both budgetary and land-use pressures at a representative installation. In an iterative process of co-design and application, we define, map, and quantify multiple ecosystem services under realistic management options. Resource management budget emerges as a major determinant of the degree to which managers can sustain both necessary training environments - a DoD-specific ecosystem service - and a prairie ecosystem with species of conservation concern. We also found clear tradeoffs between training intensity and forest-related services. Our co-developed approach brings otherwise hidden values and tradeoffs to the fore in a balanced way that can help public agencies safeguard priority services under potentially conflicting uses and budget limitations.
\end{abstract}

\section{Key words}

Biodiversity, carbon sequestration, InVEST, military training, public lands, spatially explicit model 


\section{Introduction}

Ecosystems provide a variety of benefits that sustain and fulfill human life (MA 2005), most commonly through lands serving multiple uses. Public agencies, many with mandates to support diverse objectives, are increasingly adopting an ecosystem service framework to provide a consistent basis for assessing and sustaining the multiple values of lands (USEPA 2009, Bateman et al. 2013, Ruckelshaus et al. 2013, Scarlett and Boyd 2013, Palomo et al. 2014). The Chinese government, for example, is implementing a national ecosystem assessment, coupled with national land zoning and financial compensation, to achieve protection of priority ecosystem services (Liu et al. 2008, Daily et al. 2013, Zheng et al. 2013). Across Latin America, publicprivate watershed agreements are proliferating to channel investments into hydrologic and other desired services (Pagiola 2008, Goldman-Benner et al. 2012). In the United States, the Forest Service now requires incorporating ecosystem services in national forest management plans (USDA Forest Service 2012), and the Bureau of Land Management has initiated ecosystemservice pilot studies (Bagstad et al. 2013); together these agencies manage 177 million ha of U.S. land.

Despite growing application of ecosystem service tools (Polasky et al. 2011, Goldstein et al. 2012, Nemec and Raudsepp-Hearne 2013, Bhagabati et al. 2014, Villa et al. 2014), demonstrations of practical ecosystem services approaches - jointly developed with public agencies to address their resource management challenges and at appropriate scales - are still lacking. According to a recent review, approximately $40 \%$ ecosystem services studies involved stakeholders to some degree to help identify ecosystem services, evaluate management options, and assess impacts (Seppelt et al. 2011). The stakeholder process is predominantly viewed positively among researchers (Koschke et al. 2014) as it is useful to gather information and knowledge (Koschke et al. 2014), build understanding and consensus (McNie 2007, Reed et al. 2009), increase legitimacy of analysis (Cowling et al. 2008), and promote acceptance of implementation (Menzel and Teng 2010, Cowling et al. 2008). Because of the time and financial cost, as well as institutional constraints in public land management (Menzel and Teng 2010, Koschke et al. 2014), ecosystem services approaches developed with public agencies in an interactive and iterative process are not common in practice.

To fill this gap, we illustrate an ecosystem services approach for managing multi-use landscapes through a case co-developed closely with one of the largest public land managing agencies--the U.S. Department of Defense (DoD) (Daily et al. 2015), which manages 12.1 million ha (over 1\%) of U.S. lands. While dedicated to military training and testing, these lands also host wellpreserved ecosystems and species of conservation importance. Sustaining these natural assets is a key objective for the DoD, as its natural resource policy embraces maintenance of biodiversity and ecosystem services (DoD 2011). Pertinent examples of ecosystem services include provision of realistic training environments; support for rare ecosystems with species of conservation concern; smoke and noise mitigation by natural buffers; provision of timber, clean water, and 
renewable energy; nature-based recreation opportunities for soldiers and civilians; and carbon sequestration.

Here, we examine how alternative management options for the intensity and siting of activities on DoD installations may balance potentially competing land uses for maintaining military mission and sustaining biodiversity and ecosystem services. To define, map, and value focal ecosystem benefits under each alternative, we demonstrate a practical, spatially explicit, and scenario-based approach using the Integrated Valuation of Environmental Services and Tradeoffs (InVEST) software. Working with DoD collaborators, we addressed three policy-related questions of broad relevance across agencies and regions globally:

1. How could future land-use intensity and budget variations affect ecosystem service provision?

2. How might spatial assessment of ecosystem services improve natural resources management in different areas?

3. Is it possible to enhance multiple ecosystem services efficiently, considering their tradeoffs and synergies?

\section{Co-development and application process}

\subsection{Study area}

We selected Joint Base Lewis-McChord (JBLM), a 37,000-ha joint Army/Air Force installation located in Washington, USA, as our demonstration site because of its active roles in both military training and natural resource conservation. JBLM is located within the South Puget Sound Landscape, historically a mosaic of grasslands, oak and conifer savannas, and wetlands. The landscape has transformed dramatically since European settlement, due to fire suppression, species invasions, and land conversion (Chappell and Crawford 1997).

JBLM is currently dominated by Douglas fir (Pseudotsuga menziesii (Mirb.) Franco) forests (58\%) and grasslands, primarily Puget Sound Prairie (15\%) (Fig. 1A). Only 3\% of the preEuropean South Puget Sound Prairie Ecosystem remains in Washington State, two thirds of which occurs at JBLM (Dunn 1998), where it supports three species of conservation concern. Taylor's checkerspot butterfly (Euphydryas editha taylori Edwards, 1888), streaked horned lark (Eremophila alpestris strigata Henshaw, 1884), and Mazama pocket gopher (Thomomys mazama Merriam, 1897) were candidates for listing during this study and we refer to them as such hereafter. Since completion of the study, the butterfly has been listed as endangered, the lark as threatened, and the gopher is proposed for listing (USFWS 2013a, b). Douglas fir forests have long been utilized for timber production at JBLM. The installation's diverse ecosystems also provide realistic forest and grassland environments for military training and testing.

Our study focuses on 34 designated Training Areas where military training occurs (Fig. 1A) 
within three ecological management regions (Fig. 1B). As detailed below and illustrated in Fig. 2, our approach is a holistic and iterative process comprising stakeholder engagement, scenario planning, biophysical and economic modeling, and multi-service synthesis (Daily et al. 2009, Kareiva et al. 2011, McKenzie et al. 2012, Ruckelshaus et al. 2013, Sharp et al. 2014).

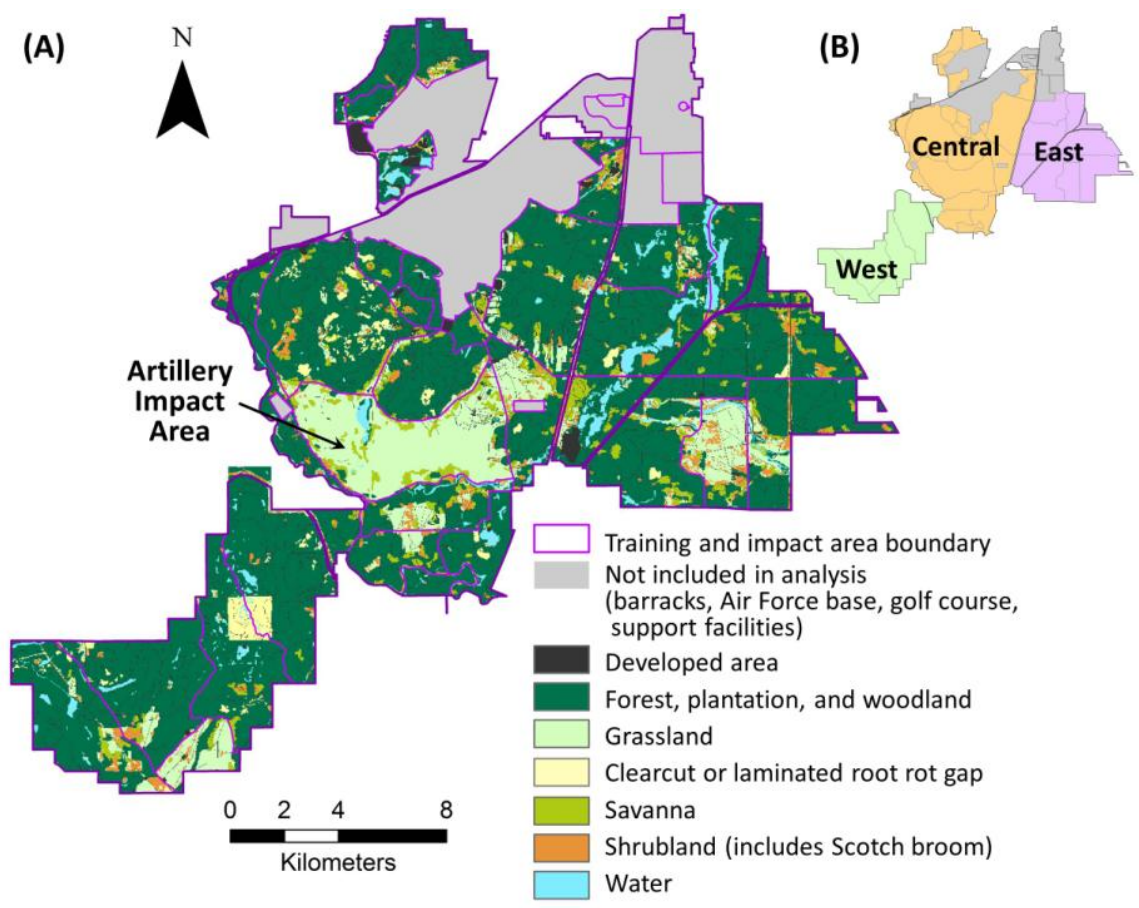

Fig. 1. (A) Land Use / Land Cover map for Joint Base Lewis-McChord (JBLM), western Washington State, USA, derived from 2007-2010 vegetation mapping and remotely sensed imagery; (B) Three ecological management regions for JBLM.

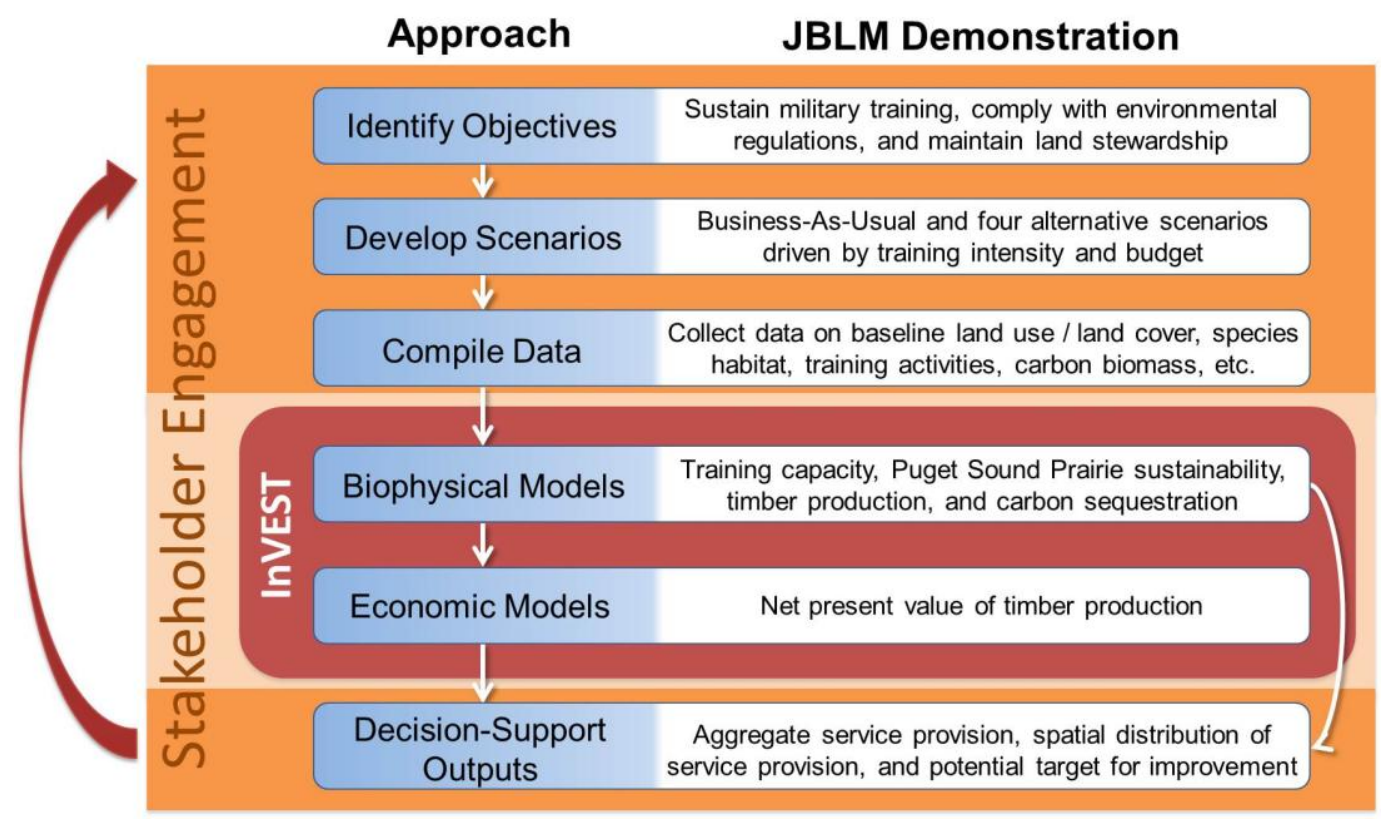


Fig. 2. Overview of a practical approach co-developed and demonstrated at JBLM. This approach is an iterative and stakeholder-engaged process that represents management scenarios as changes in land use and land cover, which are then used as inputs for science-based assessment of ecosystem services to inform management decisions. (Adapted from Guerry et al. 2012.)

\subsection{Co-development of objectives and scenarios}

We co-developed overarching objectives and a suite of realistic scenarios in a series of structured interactions with JBLM personnel. We conducted a group workshop at JBLM in November 2011 to initiate the partnership and explored major resource management objectives, concerns, subcomponents and their interactions, as well as focal ecosystem services with four installation personnel, who played critical roles in natural resource management from the divisions of Forestry, Fish and Wildlife, and Range Support. Participants offered comprehensive yet complementary information from different perspectives, yielding a solid local knowledge basis for our project. We outlined the resource management dynamics and co-developed the first narrative draft of scenarios with information collected from the workshop and follow-up individual discussions through phone calls and email exchanges.

In a subsequent two-day visit to JBLM in April 2012, we had intensive discussion with the core group of installation personnel, who participated in the previous workshop, to characterize the scenarios and qualitative measures. On the first day, we confirmed drivers of changes in resource management, resulting scenario variations, key components of each scenario, and the time scale for analysis in a group. On the second day, we further discussed the qualitative measures and spatial extents for each scenario component and reached consensus on the scenario framework. During this visit, we also conducted a number of individual meetings with the key stakeholders and other installation personnel to discuss specific issues and collect data for scenario and ecosystem service model parameterization. With these inputs from JBLM personnel, we then developed quantitative metrics and spatial delineation for Land Use / Land Cover (LULC) change in future scenarios. We finalized scenarios and confirmed all scenario and model assumptions individually with key JBLM personnel in several rounds of discussion via email and phone calls over three months.

\subsubsection{Scenario drivers}

Two important policy drivers - training intensity and the budget for natural resource management - influence future management practices and land uses for JBLM (Table 1). "Training intensity" represents the number of troops actively deployed at JBLM and frequency of training activities; generally, as these increase, so does disturbance to habitats. Training activities are also likely associated with expansion of laminated root rot (Phellinus sulphurascens 
Pilat), a root disease causing severe mortality in Douglas fir forests (Hansen and Goheen 2000), as motor vehicles transport infected woody debris with root rot spores (Foster 2009), or possibly as training activities exert additional stress on infected trees (A. Kroll, pers. comm., February 20, 2014). Root rot-infested Douglas fir forests that experience tree death and reduced canopy cover are susceptible to invasion by Scotch broom (Peterson and Prasad 1998), but can also become native shrubland or pre-commercial forest if natural or artificial regeneration is present (Foster 2009).

The "budget" for natural resource management correlates directly with the extent of invasive species control, tree planting, and grassland habitat maintenance on- and off-base (Table 1). If sufficient budget is allocated to protecting candidate species and their habitats, JBLM personnel expect potentially less stringent training restrictions imposed post-Endangered Species Act listing by the U.S. Fish and Wildlife Service on grasslands designated as either occupied or potential habitat for species listed under the Endangered Species Act.

Projecting 20 years from the 2010 baseline, these drivers define the Business-As-Usual (BAU) scenario and four alternatives: High Budget-Decreased Training (HBDT), High BudgetIncreased Training (HBIT), Low Budget-Decreased Training (LBIT), and Low Budget-Increased Training (LBDT). Alternative training intensity implies 20\% deviation from BAU based on JBLM stakeholder estimates during iterative discussions, and alternative budget leads to about $30 \%$ deviation in resource management cost from BAU based on aggregated budget calculation for natural resource management on forestry, wildlife, training lands, and off-site conservation easements using data provided by installation personnel.

\subsubsection{Baseline characterization}

We generated the 2010 LULC map using a JBLM vegetation map that combined vegetation plots and remotely sensed imagery from 2007 and 2008 (Chastain 2008). We then updated the vegetation map to include gaps created by laminated root rot mapped by JBLM staff in 2010 . Foresters at JBLM have partially mapped symptomatic laminated root rot areas (i.e., clusters of dead and dying trees, large openings not created by logging or windthrow; presence of root rot confirmed by examining roots of uprooted trees) and found that gaps currently occupy about $2 \%$ of the conifer-dominated forest area (Foster 2009). However, the foresters estimate that a total of $20 \%$ of conifer-dominated forest is actually infected, most of this area not yet symptomatic. We converted the current LULC to a raster file format at a resolution of $28.5 \mathrm{~m}$ in ArcGIS software and used it as a baseline for creating 2030 scenarios.

\subsubsection{Scenario mapping}

The alternative scenarios vary in the total area of laminated root rot infestation, Scotch broom expansion, tree planting, and training restrictions, as driven by training intensity and budget. We 
delineated the quantitative criteria spatially for each scenario from the baseline current LULC map based on stakeholder inputs and literature values (Table 1).

- "Restricted training area" refers to lands where vegetation-disturbing activities (e.g., offroad maneuvering, digging, and bivouacking) are prohibited to protect species that were candidates for listing during the study, cultural resources, and wetlands. We delineated training restrictions based on current restrictions, habitat occupied by the candidate species, and/or potential habitat for candidate species provided by relevant JBLM personnel.

- "Laminated root rot area" represents the proportion of susceptible forest infected by root rot. We assumed areas of new infections have an expansion rate of $3 \mathrm{~m} / \mathrm{year}$ and expand from both existing infected areas and randomly placed new infection sites. The spread rate is difficult to define as it depends on many factors, such as stand density, host species composition, inoculum density of the pathogen, and stress placed onto host trees (A. Kroll and D. Omlan, pers. comm., February 20, 2014). Studies in the Oregon Cascades showed an average fungus spread rate ranged $5 \sim 58 \mathrm{~cm} /$ year via root-to-root contact (McCauley and Cook 1980, Nelson and Hartman 1975). Root rot sporophores are also found on woody debris from infected trees (Washington Academy of Sciences 2013) and may be carried via motor vehicles during training activities (Foster 2009), but dispersal rates via spores are not well documented. We chose a higher rate of $3 \mathrm{~m} /$ year to reflect natural root-to-root contact combined with the increased stress on infected trees and dispersal of infected woody debris due to training activities based on discussion with installation personnel and experts.

- "Tree replanting area" represents the proportion of laminated root rot infected areas replanted with immune or resistant tree. We randomly selected canopy gaps formed by root rot over 0.4 ha in size for planting until scenario criteria were met. According to installation forestry expert, gaps less than 0.4 ha are usually not planted because there is insufficient direct sunlight for adequate growth of planted trees.

- "Scotch broom-dominated area in grassland" represents the extent of Scotch broom in grassland habitat. It was simulated by randomly selecting pixels within grasslands to match scenario criteria. We assumed that Scotch broom and grassland vegetation can occur interchangeably under different management scenarios based on the experience from JBLM and other grassland owners in the South Puget Sound who have been controlling Scotch broom for up to 20 years.

We made two additional assumptions about land conversion based on discussion with foresters at JBLM. First, all scenarios assumed areas infected with laminated root rot, but not replanted with immune or resistant tree species, will become 50\% Scotch broom, 25\% native shrubs, and 25\% pre-commercial conifer from natural regeneration, and infected forest pixels are randomly converted to meet these criteria based on discussion with installation forestry expert. Scotch broom inhibits tree sapling growth in forest plantations (Peterson and Prasad 1998, Foster 2009). 
JBLM personnel's experience indicates that, unless there is a pre-existing native shrub layer, Scotch broom will germinate in nearly all logging- or root rot-mortality openings and compete with natural and planted tree regeneration. Native shrubs are established understories of Douglas fir forest at JBLM. If there is a pre-existing native shrub layer, it is likely to persist, suppressing Scotch broom. If sufficient advance regeneration is present, trees will dominate the site. Second, in discussion with installation personnel, we assume 50\% of an existing 260 ha clearcut area in the west region will convert to mature conifer plantation for all five future scenarios, while the other $50 \%$ will convert to Scotch broom. We also assumed stochastic biological (e.g., species invasions and extirpations) and climatic forces (e.g., droughts, early/late frosts, etc.) affect habitat conditions and management effectiveness of alternative scenarios with equal probabilities, and thus will not trigger cross-scenario variations. In reality, differential effects are likely.

Table 1. Summary of assumptions for 2030 management scenarios at Joint Base LewisMcChord, WA.

\begin{tabular}{|c|c|c|c|c|c|c|}
\hline LULC & Pol & y Drivers & & LUL & Features & \\
\hline changes & $\begin{array}{c}\text { Budget } \\
\text { for natural } \\
\text { resource } \\
\text { management }\end{array}$ & $\begin{array}{l}\text { Training } \\
\text { intensity } \\
\text { troop number } \\
\text { \& training } \\
\text { frequency }\end{array}$ & $\begin{array}{c}\text { Restricted } \\
\text { training area } \\
\text { for candidate } \\
\text { risk } \\
\text { protection } \\
\end{array}$ & $\begin{array}{c}\text { Laminated } \\
\text { Root Rot } \\
\text { (LRR) area } \\
\text { infected in } \\
20 \text { years } \\
\end{array}$ & $\begin{array}{c}\text { Tree } \\
\text { replanting } \\
\text { area } \\
\text { with immune } \\
\text { species } \\
\end{array}$ & $\begin{array}{c}\text { Scotch } \\
\text { broom } \\
\text {-dominated } \\
\text { area in } \\
\text { grassland } \\
\end{array}$ \\
\hline $\begin{array}{c}\text { High } \\
\text { Budget- } \\
\text { Decreased } \\
\text { Training }\end{array}$ & High & $20 \% \downarrow$ & $\begin{array}{l}\text { Reduced } \\
\text { restrictions in } \\
\text { occupied } \\
\text { habitat } \\
(4,904 \text { ha) }\end{array}$ & $\begin{array}{l}20 \% \\
\text { susceptible } \\
\text { forest } \\
(3,151 \mathrm{ha})\end{array}$ & $\begin{array}{l}80.9 \text { ha/year } \\
\text { of LRR- } \\
\text { infested area }\end{array}$ & $\begin{array}{l}10 \% \\
\text { everywhere } \\
(522 \mathrm{ha})\end{array}$ \\
\hline $\begin{array}{c}\text { High } \\
\text { Budget- } \\
\text { Increased } \\
\text { Training }\end{array}$ & High & $20 \% \uparrow$ & $\begin{array}{l}\text { Reduced } \\
\text { restrictions in } \\
\text { occupied } \\
\text { habitat } \\
(4,904 \mathrm{ha})\end{array}$ & $\begin{array}{l}40 \% \\
\text { susceptible } \\
\text { forest } \\
(6,301 \mathrm{ha})\end{array}$ & $\begin{array}{l}80.9 \mathrm{ha} / \mathrm{year} \\
\text { of LRR- } \\
\text { infested area }\end{array}$ & $\begin{array}{l}10 \% \\
\text { everywhere } \\
(522 \mathrm{ha})\end{array}$ \\
\hline $\begin{array}{l}\text { Business- } \\
\text { As-Usual }\end{array}$ & Medium & Medium & $\begin{array}{l}\text { Most } \\
\text { occupied } \\
\text { habitat } \\
(5,904 \text { ha })\end{array}$ & $\begin{array}{l}30 \% \\
\text { susceptible } \\
\text { forest } \\
(4,726 \mathrm{ha})\end{array}$ & $\begin{array}{l}40.5 \mathrm{ha} / \mathrm{year} \\
\text { of LRR- } \\
\text { infested area }\end{array}$ & $\begin{array}{l}10 \% \\
\text { occupied } \\
\text { habitat; } 25 \% \\
\text { elsewhere } \\
(1,013 \text { ha) }\end{array}$ \\
\hline $\begin{array}{c}\text { Low } \\
\text { Budget- } \\
\text { Decreased } \\
\text { Training }\end{array}$ & Low & $20 \% \downarrow$ & $\begin{array}{l}\text { All occupied } \\
\& \text { potential } \\
\text { habitat } \\
(8,730 \mathrm{ha})\end{array}$ & $\begin{array}{l}20 \% \\
\text { susceptible } \\
\text { forest } \\
(3,151 \mathrm{ha})\end{array}$ & $\begin{array}{l}20.2 \mathrm{ha} / \mathrm{year} \\
\text { of LRR- } \\
\text { infested area }\end{array}$ & $\begin{array}{l}25 \% \\
\text { restricted } \\
\text { area; } 75 \% \\
\text { elsewhere } \\
(2,282 \text { ha) }\end{array}$ \\
\hline $\begin{array}{c}\text { Low } \\
\text { Budget- } \\
\text { Increased } \\
\text { Training }\end{array}$ & Low & $20 \% \uparrow$ & $\begin{array}{l}\text { All occupied } \\
\& \text { potential } \\
\text { habitat } \\
(8,730 \mathrm{ha})\end{array}$ & $\begin{array}{l}40 \% \\
\text { susceptible } \\
\text { forest } \\
(6,301 \mathrm{ha})\end{array}$ & $\begin{array}{l}20.2 \mathrm{ha} / \mathrm{year} \\
\text { of LRR- } \\
\text { infested area }\end{array}$ & $\begin{array}{l}25 \% \\
\text { restricted } \\
\text { area; } 75 \% \\
\text { elsewhere } \\
(2,282 \text { ha })\end{array}$ \\
\hline
\end{tabular}




\subsection{Ecosystem services modeling}

We used InVEST, an open-source software suite (Kareiva et al. 2011, Sharp et al. 2014), to evaluate ecosystem services under future scenarios. During our initial stakeholder workshop, we jointly identified five priority ecosystem services with JBLM personnel and co-defined their scopes for the base. These services include infantry training capacity, vehicle training capacity, sustainability of Puget Sound Prairie, timber production, and carbon sequestration, the first two of which required co-developing new approaches. Because Puget Sound Prairie includes multiple species of conservation concern, we use "ecosystem provision of habitat" as a proxy for biodiversity, i.e., persistence of candidate, proposed, or listed species (Keith et al. 2013). Timber production from Douglas fir forest provides income for natural resource management at JBLM. Finally, potential regulation for carbon sequestration on public lands drives DoD to consider carbon dynamics. These services are interconnected via LULC, providing an opportunity to observe tradeoffs and synergies that can inform management decisions.

\subsubsection{Training capacity}

Different natural environments, such as forests and grasslands, simulate potential battlefields, enabling realistic training on installations, and thus improving military preparedness. We codesigned a new model to quantify the provision of natural habitat supporting infantry and vehicle training on installations as an ecosystem service (hereafter 'training capacity'). Training capacity was calculated in terms of usable land area for infantry and vehicle training activities, based on suitability and connectivity of LULC, frequency of training, and seasonal or annual restrictions on off-road vehicle maneuvering.

We calculated the area of natural habitat usable for infantry and vehicle training in 29 Training Areas at JBLM. Infantry training activities, which involve field operations and maneuvers on foot, occur in most landscapes except large areas of surface water or dense shrublands (including Scotch broom). In contrast, vehicle training activities using tracked or wheeled motor vehicles typically rely on roads and large, open areas, such as prairie, savanna, and low-height shrubland. Live-fire weapons training is not included in this model because it primarily occurs on designated firing ranges within impact areas and is not likely to be affected under alternative scenarios.

We first estimated total suitable and accessible habitat areas for infantry and vehicle training respectively using maps of LULC and roads. JBLM staff suggested Scotch broom habitat becomes unsuitable for training when tall shrubs cover more than one third of habitat. As training restrictions prohibiting off-road vehicle movement are imposed in some prairie areas to protect species of conservation concern (e.g., Mazama pocket gopher and Taylor's checkerspot butterfly), we subtract those restricted habitats for vehicle training. Additionally, some areas are unavailable for vehicle training during the nesting and breeding seasons of sensitive bird species 
(half the year for bald eagle; one-third of the year for streaked horned lark). We included the area of roads in both infantry and vehicle training capacities because they are extensively used by troops to access training areas. To obtain actual infantry and vehicle training capacities, the resulting suitable training habitat is multiplied by the percentage of a year that training activities occur in each zone. The percentage falls into four levels (100\%, 70\%, 40\%, and 10\%) based on discussion with JBLM personnel (I. Gruhn, pers. comm., September 6, 2012). Training areas are more frequently used for both infantry and vehicle training if they are closer to barracks, have more open space, and are free of natural barriers such as rivers. We derived most changes in inputs under alternative scenarios from LULC maps.

\subsubsection{Habitat risk assessment}

We used the Habitat Risk Assessment model (Sharp et al. 2014) to evaluate risks posed to the persistence of prairie habitat by stressors at JBLM, including seven training activities (digging, off-road vehicles, camping, flight operations, foot training, ordnance, firing range training) and invasive Scotch broom. This model combines information about exposure of habitat to each stressor with information about consequences of exposure, given resilience of the habitat (Hobday et al. 2011). Exposure depends on spatial and temporal overlap between habitat and a stressor, stressor intensity, and effectiveness of management strategies mitigating stressor impacts. Consequence depends on change in habitat area and structure due to the stressor, frequency of disturbance relative to natural disturbance regime, and attributes associated with recovery likelihood (i.e., natural rates of dispersal, maturity, reproduction, and mortality; De Lange et al. 2010; Folke et al. 2004).

For each stressor, we scored model inputs from 1-3 (low, medium, or high), based on standard criteria in the model (Sharp et al. 2014). We used maps of training restrictions, training manuals, and interviews with JBLM personnel to determine the extent of spatial and temporal overlap between training stressors and prairie habitat in each Training Area. Spatial overlap between training stressors and prairie habitat remained the same in all scenarios. However, spatial overlap between Scotch broom and prairie habitat was greater in low-budget than high-budget scenarios. To classify temporal overlap between training stressors and prairie habitat, we multiplied the percent of a year in which an area was unrestricted by the frequency of training use per year and scored values from 0.67-1.00 as "high", 0.33-0.66 as "medium", and below 0.33 as "low". We assumed greater training restrictions, and thus less temporal overlap, in low-budget than highbudget scenarios and classified temporal overlap as "none" where year-round restrictions eliminated presence of the stressor. We assumed year-round overlap between Scotch broom and prairie habitat in all scenarios.

For all stressors except Scotch broom, off-road vehicles, and ordnance training, we classified both intensity and management effectiveness as "medium" under the BAU scenario, intensity as "low" and management effectiveness as "high" under scenarios with decreased training, and 
intensity as "high" and management effectiveness as "low" under scenarios with increased training (Table 2). We classified the intensity of Scotch broom as "high" under all scenarios because detrimental effects of the shrub on the Puget Sound Prairie Ecosystem are well documented (Table 2; JBLM 2007, USFWS 2013a, b). We scored management effectiveness higher for off-road vehicles and ordnance training than other stressors under BAU and decreased training scenarios (Table 2) because periodic disturbance by these activities are managed to provide openings in prairie beneficial to nesting and movement of sensitive bird species (JBLM, 2007; Pearson et al., 2005).

Table 2. Habitat Risk Assessment model inputs for exposure to and consequences of stressors at Joint Base Lewis-McChord, WA, categorized as High, Medium (Med), or Low for each scenario.

\begin{tabular}{|c|c|c|c|c|c|c|c|c|c|}
\hline \multirow[b]{3}{*}{ Stressors } & \multicolumn{6}{|c|}{ Exposure* } & \multicolumn{3}{|c|}{ Consequence $* *$} \\
\hline & \multicolumn{3}{|c|}{ Stressor intensity } & \multicolumn{3}{|c|}{ Management effectiveness } & \multirow{2}{*}{$\begin{array}{l}\Delta \text { in area } \\
\text { All }\end{array}$} & \multirow{2}{*}{$\begin{array}{l}\Delta \text { in structure } \\
\text { All }\end{array}$} & \multirow{2}{*}{$\begin{array}{l}\Delta \text { disturbance frequency } \\
\text { All }\end{array}$} \\
\hline & BAU & $\begin{array}{l}\text { HBDT } \\
\text { and } \\
\text { LBDT } \\
\end{array}$ & $\begin{array}{l}\text { HBIT } \\
\text { and } \\
\text { LBIT }\end{array}$ & BAU & $\begin{array}{l}\text { HBDT } \\
\text { and } \\
\text { LBDT } \\
\end{array}$ & $\begin{array}{l}\text { HBIT } \\
\text { and } \\
\text { LBIT } \\
\end{array}$ & & & \\
\hline Off-road vehicles & Med & Low & High & High & High & Med & Low & Med & Med \\
\hline Digging & Med & Low & High & Med & High & Low & Med & High & Low \\
\hline Bivouacking & Med & Low & High & Med & High & Low & Low & Low & Low \\
\hline Foot training & Med & Low & High & Med & High & Low & Low & Low & Med \\
\hline Ordnance & Med & Low & High & High & High & Med & Med & Low & Low \\
\hline Training range & Med & Low & High & Med & High & Low & Med & Med & Med \\
\hline Flight operations & Med & Low & High & Med & High & Low & Low & High & Med \\
\hline Scotch broom & High & High & High & Med & High & Low & High & High & Low \\
\hline
\end{tabular}

*Exposure also includes spatial and temporal overlap (see text)

**Consequence also includes attributes of resilience (see text)

We combined information from literature and discussion with biologists at JBLM to score loss in prairie area and structure with each stressor (Chappell and Crawford 1997; Crawford and Hall 1997; Quist et al. 2003; Whitecotton et al. 2000) and to determine sources and frequency of historic disturbance in the Puget Sound Prairie Ecosystem (Table 2; Chappell and Crawford 1997; Crawford and Hall 1997). We classified the effect of a stressor as "high" when analogous historical disturbances (e.g., digging, foot traffic, or fires by Native Americans, conifer encroachment) occurred either much more or less frequently than stressor disturbance, "medium" with slightly more or less frequent occurrence, and "low" when disturbance frequencies were similar (Table 2).

We reviewed literature to assess the resilience of prairie habitat based on natural rates of mortality, recruitment, maturity, and dispersal for Roemer's fescue (Festuca roemeri), the dominant native plant in the Puget Sound Prairie Ecosystem (30-70\% cover in high-quality native prairie; Chappell and Crawford 1997; Crawford and Hall 1997; Darris et al. 2012). Because Roemer's fescue is a long-lived perennial bunchgrass that does not typically flower 
until its second full growing season and has little dispersal between populations (Chappell and Crawford 1997; Crawford and Hall 1997; Darris et al. 2012), we classified maturity, reproduction, and mortality for Puget Sound Prairie Ecosystem as "medium" and connectivity as "low". The InVEST HRA model assumes species and/or habitats with rapid lifecycles (i.e., high mortality and recruitment rates and short times until maturity) and frequent dispersal between populations should be those most resilient to the effects of stressors (De Lange et al., 2010; Folke et al., 2004).

Scoring of model inputs for the Habitat Risk Assessment Model has the potential to be a timeconsuming and contentious process. We were able to avoid such pitfalls by relying on a small number of personnel with intimate knowledge of the study system, as well as peer-reviewed literature, to guide our scoring. Furthermore, we were able to conduct our scoring after previous stressor identification and scoring, conducted during creation of a draft Candidate Conservation Agreement and Candidate Conservation Agreement with Assurances for Puget Sound Prairie Species (G. Reub, personal communication; Duggan et al. 2015). Thus, JBLM personnel had prior experience scoring stressor exposure and consequences based on expert opinion and were comfortable with the process.

To classify model output into low- or high-risk areas, we examined relationships between risk and vegetation cover in 25-m quadrats surveyed across JBLM. A regression analysis indicated a negative relationship between predicted risk and percent native grass cover (Nagelkerke's $R^{2}=$ $\left.0.24, F_{1,23}=8.64, P<0.007\right)$. Using this relationship, we determined risk associated with the percent native grass cover on no-risk habitat (i.e., no modeled stressors present). Where stressors were present, we summarized habitat as low- or high-risk using a threshold value associated with a $33 \%$ decrease in native grass cover from no-risk habitat. We examined our characterization of risk by using chi-square analyses to test if the current distribution of three species of conservation concern that we consider "characteristic native biota" of the Puget Sound Prairie Ecosystem (Keith et al. 2013, Rodríguez et al. 2012) differed among high- and low-risk categories from that expected given total availability of high- and low-risk area predicted across potential habitat at JBLM under current conditions.

\subsubsection{Managed timber production}

We applied the InVEST Timber Production model (Sharp et al. 2014) to calculate expected net present value (NPV) of timber harvested during 2010-2030 from Douglas fir forest at JBLM. The model runs on user-defined timber management zones, each of which is characterized by its total area, proportion of total area harvested each period, volume of wood harvest each period, frequency of harvest, as well as harvest and maintenance costs. With inputs of timber price and a discount rate, the model calculates NPV of harvests on each zone during a user-defined period of time. 
We ran the model on three ecological management zones (Fig. 1B) containing a total of $\sim 700$ harvest stands auctioned in past timber sales. Because individual stands were not regularly managed and timber sales often spatially overlapped, we aggregated harvest information from stands into management zones to model timber harvest in a consistent manner. We estimated net return of timber for each year by subtracting total maintenance costs from total timber sale revenue, which was calculated as the product of harvest area, wood volume per unit area, and timber price corrected for inflation. We obtained the NPV of timber by discounting flow of future net returns to the base year 2010 .

For all scenarios, timber harvest occurs every year in each zone. We assumed timber volume harvested per unit area was consistent with historical practices for each zone, which was estimated as a ten-year average based on 2002-2011 JBLM timber sale records (Table 3). However, total area of each zone and proportion of total area harvested each year were assumed to vary across scenarios, and were determined by the availability of forest resources. In decreased training scenarios (HBDT and LBDT), we calculated total harvest area and proportion of total area harvested as ten-year averages of 2002-2011 data because root rot infestation remains at its current rate (20\% of susceptible forest). Although the infestation rate increased to $30 \%$ under BAU, JBLM staff suggested the total timber harvest would remain at the current level in BAU by increasing the proportion of area harvested to offset loss in total area. When root rot infests $40 \%$ of susceptible forest under increased training scenarios (HBIT and LBIT), the total harvest area would decrease annually by $0.67 \%-0.79 \%$, and the proportion of total area harvested increases by $0.58 \%-0.67 \%$ /year in HBIT and $0.33 \%-0.44 \% / y e a r$ in LBIT to maintain the same harvest per unit area as BAU (Table 3).

The inputs for price and cost were consistent across scenarios. We assumed no harvest costs for JBLM, as timber is mostly harvested by logging companies or individuals who won timber sale auctions. We calculated maintenance cost, which covers small-scale reforestation and control of invasive plants (e.g., Scotch broom) and disease (e.g., laminated root rot), based on 2007-2011 data from the JBLM Forestry program. We estimated baseline timber price as the ten-year average of per-volume bid revenue from the 2002-2011 timber bid reports. It was deflated by the all-commodity producer price index (BLS 2012) and adjusted by regional stumpage price index to account for timber market fluctuation (WSDOR 2012). We projected future price variation during 2010-2030 based on the 2005 USDA Forest Service's assessment (Haynes et al. 2007). We derived the NPV of timber using a discount rate of $3 \%$ recommended by the Office of Management and Budget (OMB 2011). 
Table 3. InVEST Timber Production Model inputs under Business-As-Usual (BAU) and four alternative scenarios at Joint Base Lewis-McChord, WA.

\begin{tabular}{|c|c|c|c|c|}
\hline Inputs for scenarios & Unit & West Zone & Central Zone & East Zone \\
\hline Total area of management zone & ha & 5061 & 7440 & 6643 \\
\hline (Annual decrease in HBIT \& LBIT) & & $(0.79 \%)$ & $(0.67 \%)$ & $(0.69 \%)$ \\
\hline Proportion of total area harvested each year & $\%$ & 5.53 & 4.12 & 4.86 \\
\hline (Annual increase in HBIT) & & $(0.67 \%)$ & $(0.62 \%)$ & $(0.58 \%)$ \\
\hline (Annual increase in LBIT) & & $(0.44 \%)$ & $(0.33 \%)$ & $(0.35 \%)$ \\
\hline Volume harvested per unit area each year & cubic meter/ha & 31.2 & 33.9 & 21.1 \\
\hline Marketplace value of wood harvested & \$/cubic meter & 120 & 110 & 113 \\
\hline Annualized maintenance cost & $\$ /$ ha & 9.9 & 7.4 & 8.7 \\
\hline Number of years valued & year & 20 & 20 & 20 \\
\hline
\end{tabular}

\subsubsection{Carbon storage and sequestration}

We used the InVEST Carbon Storage and Sequestration model (Sharp et al. 2014) to evaluate the carbon sequestration service (measured in million grams) provided by aboveground biomass, belowground biomass, and harvested wood products from 2010 to 2030 at JBLM. The InVEST model aggregates the amount of carbon stored in carbon pools and calculates the sequestration between current and future LULC scenarios. Each cell in the raster is assigned a LULC class such as forest, pasture, or agricultural land. For each LULC type, the model requires an estimate of the amount of carbon in at least one of the four fundamental pools - aboveground biomass, belowground biomass, soil, and dead organic matter - and a fifth optional pool for harvested wood products. For harvested wood products, model values are defined for each timber harvest parcel - the amount of biomass removed per harvest, harvest frequency, and rate at which carbon degrades within products. The model calculates the amount of stored carbon that originated in a parcel but now resides in finished products.

For JBLM, we derived carbon values for LULC classes using the National Biomass and Carbon Dataset (NBCD, Kellndorfer et al. 2000). We calculated aboveground biomass by aggregating vegetation types into structural classes and averaging biomass values for each class (Table 4). Since the NBCD only provides values for tree and some shrub species, we valued aboveground biomass for Scotch broom at 47.0 Mg/ha (Bossard and Rejmanek 1994; Wheeler et. al. 1987) and cold temperate prairies at $2.4 \mathrm{Mg} / \mathrm{ha}$ (IPCC 2006) based on available scientific literature. We converted mean aboveground biomass to carbon storage $(\mathrm{Mg} / \mathrm{ha})$ by multiplying the aboveground biomass value by 0.5 (IPCC 2006). We calculated belowground carbon storage by multiplying aboveground carbon by a root to shoot ratio of 0.3 , the average for temperate forest species, or 4.0 for prairie species (IPCC 2006). We calculated harvested carbon pools using the timber product estimate from the InVEST Timber Production model and decay rates for Douglas-fir sawtimber (34 years half-life) and pulpwood (1 year half-life) (Smith et al. 2006). 
We captured carbon biomass from root rot-infested trees that are salvage-logged in the harvest product pool and assumed the remaining infested trees decay naturally onsite. We evaluated carbon sequestration for each scenario as the total biomass stored between 2010 and 2030. Due to data limitations, we assumed carbon accumulation in intact secondary and old growth forests did not change spatial forest classifications or scenario parameters. Due to difficulties in assessing stand age, we did not include carbon stored in soil and dead organic matter in calculations.

We compared the mean values of aboveground carbon for several vegetation classes using the NBCD dataset and validation data from field sampling acquired in 2012 (M. Hurteau, Penn State Univ., unpublished data). The mean values for NBCD have considerable overlap with estimates based on field sampling, although values are slightly lower (Fig. 3), which may be a result of growth in tree biomass given the 12-year difference between datasets. This comparison suggests that the InVEST Carbon Storage and Sequestration model with NBCD data reasonably estimates carbon biomass stored in various vegetation types and can be used for decisions relying on relative estimates.

Table 4. Mean values, upper bounds, and lower bounds for Land Use and Land Cover (LULC) structural classes and types at Joint Base Lewis-McChord, WA, derived from the National Biomass and Carbon Dataset (NBCD) and Intergovernmental Panel on Climate Change (IPCC) root-to-shoot ratios.

\begin{tabular}{lcc}
\hline \multicolumn{1}{c}{ LULC Type } & $\begin{array}{c}\text { Aboveground C } \\
\text { (Mg/ha) }\end{array}$ & $\begin{array}{c}\text { Belowground C } \\
\text { (Mg/ha) }\end{array}$ \\
\hline Bare ground & 0 & 0 \\
Built-up in training area & 0 & 0 \\
Conifer plantation & 110.6 & 33.2 \\
Conifer riparian forest & 188.4 & 56.5 \\
Deciduous forest & 95.8 & 28.7 \\
Deciduous plantation & 72.8 & 21.8 \\
Deciduous woodland & 92.5 & 27.8 \\
Developed & 0 & 0 \\
Douglas-fir forest & 180.8 & 54.2 \\
Douglas-fir woodland & 130.9 & 39.3 \\
Grassland & 1.2 & 4.8 \\
Hardwood riparian forest & 114.5 & 34.4 \\
Lake & 0 & 0 \\
Mixed forest & 120 & 36 \\
Mixed woodland & 117 & 35.1 \\
Native shrubland & 83.9 & 25.2 \\
Recent burn/clearcut & 111.7 & 33.5 \\
Savanna & 93.4 & 28 \\
Scotch broom & 23.5 & 7.1 \\
Stream & 0 & 0 \\
Non-forested Wetland & 0 & 0 \\
\hline
\end{tabular}




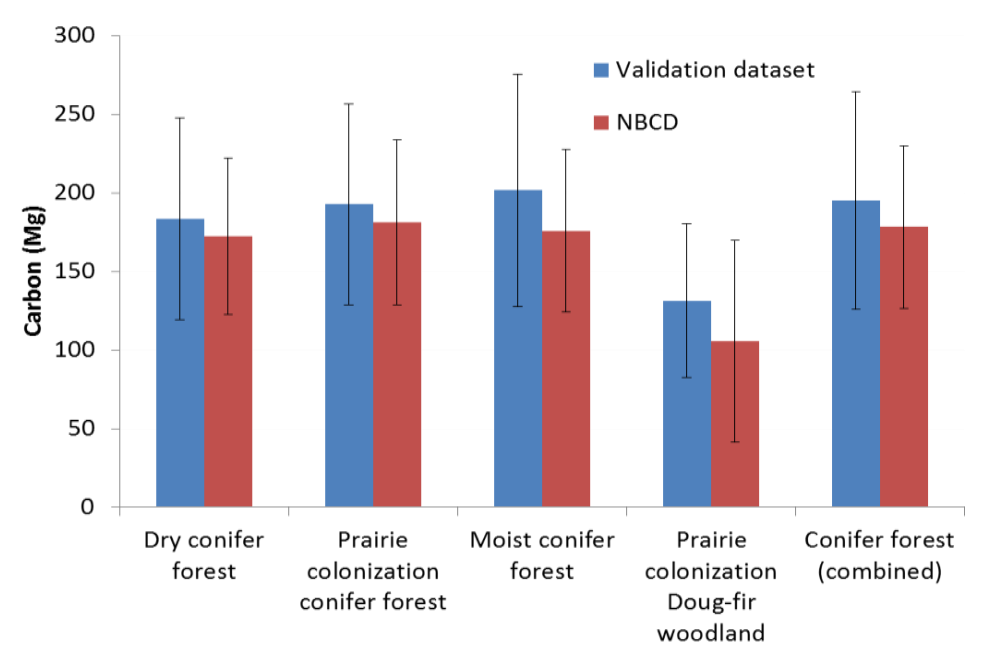

Fig. 3. Mean carbon storage of vegetation classes using a 2012 validation dataset and the 2000 National Biomass and Carbon Dataset (NBCD) at Joint Base Lewis-McChord, WA. Error bars represent one standard deviation from the mean carbon storage.

\subsection{Co-evaluating tradeoffs and synergies among multiple ecosystem services and biodiversity}

Based on our discussion with JBLM stakeholders, we synthesized ecosystem services modeling results to address three policy questions outlined in the introduction. To examine Question 1, which asks how information on ecosystem services affects training and budgetary decisions, we compared the percentage change of ecosystem service provision for each alternative scenario relative to BAU. We measured biodiversity provision as total low-risk habitat area, training capacities as total usable habitats for infantry and vehicle training, respectively, carbon sequestration as total carbon biomass stored between 2010-2030, and timber production as total net present value in 2010-2030. Then, to address Question 2 about the magnitude of ecosystem service in specific areas, we mapped the spatial distribution of ecosystem benefits as the relative contribution of each Training Area to total provision. We ranked all Training Areas based on a measure combining absolute service provision with efficiency of provision (measured as service per unit functional area). We used a "service gap" map to further illustrate difference in provision for each ecosystem service between extreme scenarios, HBDT and LBIT, in each Training Area. We identified the lowest number of Training Areas able to fill service gaps $\geq$ $25 \%$, thus revealing priority Training Areas that can improve service provision with increased budget and decreased training intensity. We highlighted tradeoffs and synergies among training, biodiversity, and other ecosystem service objectives (Question 3) amid the aggregate and spatially explicit assessment of ecosystem services.

To understand how an ecosystem services approach can aid in the natural resource decisionmaking process for JBLM and the DoD in general, we conducted structured phone interviews in August 2012 with four JBLM personnel individually. We spoke with each representative for 30- 
45 minutes to clarify current procedures for environmental management and to understand their perspectives on the added value of an ecosystem services approach. Respondents were posed questions that focused on their specific role in environmental decision-making, their understanding and opinion of ecosystem services valuation, and the presence of the Army's mission-oriented sustainability approach at JBLM.

In September 2012, we presented preliminary ecosystem services assessment results and management implications in a plenary meeting with nine JBLM personnel including key personnel who participated in scenario development and model parameterization and others who would potentially use the results, such as environmental compliance specialists, military training area managers, and geo-spatial technicians. Participants of the workshop provided valuable feedback on the approach, ecosystem services modeling results, and potential management applications. We further revised the scenarios and parameter values according to stakeholder feedback and shared the updated results with relevant stakeholders in 2013.

\section{Results}

\subsection{Aggregate analysis of ecosystem services}

Training intensity and the budget for resource management influence ecosystem service provision in different directions and magnitudes across scenarios (Table 5 and Fig. 4). Compared with BAU, the two scenarios with increased training intensity reveal an obvious decline in carbon sequestration and timber production because vehicle movement associated with training activities increases the proportion of susceptible forest infected with root rot. Whereas the HBIT scenario decreases carbon sequestration by $46 \%\left(1.09 * 10^{5} \mathrm{Mg}\right.$ biomass) and the 20 -year timber net present value by $15 \%$ ( $\$ 11.3$ million), the LBIT scenario results in $62 \%\left(1.47 * 10^{5} \mathrm{Mg}\right)$ and $17 \%$ ( $\$ 12.8$ million) reduction in these services, respectively. The decreased training scenarios (HBDT and LBDT) exhibit comparable gain in carbon sequestration $\left(\sim 50 \% ; \sim 1.2 * 10^{5} \mathrm{Mg}\right)$, but not in timber production, because timber harvest generally remains constant across years unless significant decline of timber resources occurs. Budget availability, which determines on- and offbase habitat maintenance and consequent restrictions on vehicle maneuvering, causes a $\sim 20 \%$ $(\sim 1,000$ ha suitable training area) decrease in vehicle training capacity for two low-budget scenarios (LBDT and LBIT) relative to BAU. The high-budget scenarios generate a minor increase $(\sim 5 \% ; \sim 1,000 \mathrm{ha})$ in vehicle training capacity. 
Table 5. Ecosystem service provision for each scenario (absolute provision and percentage changes relative to Business-As-Usual [BAU]) at Joint Base Lewis-McChord, WA.

\begin{tabular}{cccccc}
\hline Ecosystem Service & $\begin{array}{c}\text { Infantry } \\
\text { Training } \\
\text { Capacity }\end{array}$ & $\begin{array}{c}\text { Vehicle } \\
\text { Training } \\
\text { Capacity }\end{array}$ & $\begin{array}{c}\text { Puget Sound } \\
\text { Prairie } \\
\text { Sustainability }\end{array}$ & $\begin{array}{c}\text { Timber } \\
\text { Production }\end{array}$ & $\begin{array}{c}\text { Carbon } \\
\text { Sequestration }\end{array}$ \\
Measure & $\begin{array}{c}\text { Suitable } \\
\text { area } \\
(1000 \text { ha) }\end{array}$ & $\begin{array}{c}\text { Suitable } \\
\text { area } \\
(1000 \text { ha) }\end{array}$ & $\begin{array}{c}\text { Low-risk } \\
\text { habitat } \\
(1000 \text { ha) }\end{array}$ & $\begin{array}{c}\text { Net present } \\
\text { value } \\
(1 \mathrm{M} \$)\end{array}$ & $\begin{array}{c}\text { Biomass } \\
(1000 \mathrm{Mg})\end{array}$ \\
\hline High Budget- & 16.9 & 4.86 & 5.77 & 74.9 & 375 \\
Decreased Training & $(7 \%)$ & $(5 \%)$ & $(28 \%)$ & $(0 \%)$ & $(57 \%)$ \\
High Budget- & 16.0 & 4.90 & 4.45 & 63.6 & 130 \\
Increased Training & $(1 \%)$ & $(6 \%)$ & $(-1 \%)$ & $(-15 \%)$ & $(-46 \%)$ \\
Business-As-Usual & 15.9 & 4.62 & 4.51 & 74.9 & 239 \\
Low Budget- & $(0 \%)$ & $(0 \%)$ & $(0 \%)$ & $(0 \%)$ & $(0 \%)$ \\
Decreased Training & $(1 \%)$ & $(-23 \%)$ & $(0 \%)$ & $(0 \%)$ & $(44 \%)$ \\
Low Budget- & 15.1 & 3.60 & 3.98 & 62.1 & 92 \\
Increased Training & $(-5 \%)$ & $(-22 \%)$ & $(-12 \%)$ & $(-17 \%)$ & $(-62 \%)$ \\
\hline
\end{tabular}

The area sustaining Puget Sound Prairie is jointly affected by budget-driven habitat maintenance and threats imposed by training activities. It ranges from an increase of $28 \%$ (1,300 low-risk ha) in HBDT to a decrease of $-12 \%$ (530 low-risk ha) in LBIT, relative to BAU. Two intermediate scenarios, HBIT and LBDT, result in a low-risk area similar to BAU. Infantry training is mobile and adaptable to most environments on the installation, and Scotch broom infestation accounts for its small variations. Scotch broom infestation is primarily driven by decreased budget for invasive species control, but it can also relate to increased training intensity that triggers root rot expansion and subsequent Scotch broom invasion. As a result, infantry training capacity changes little across scenarios; indeed, no difference occurs between the two intermediate scenarios (HBIT and LBDT) in which budget and training intensity offset each other. Across services, the HBDT scenario has the highest provision in all ecosystem services and the LBIT scenario provides the least. When considering only ecosystem services pertaining to the military mission (i.e., infantry and vehicle training) and regulatory training constraints (i.e., candidate species associated with Puget Sound Prairie), both high-budget scenarios result in no service degradation relative to BAU, with considerable gain in area sustaining Puget Sound Prairie (28\%) by HBDT. 


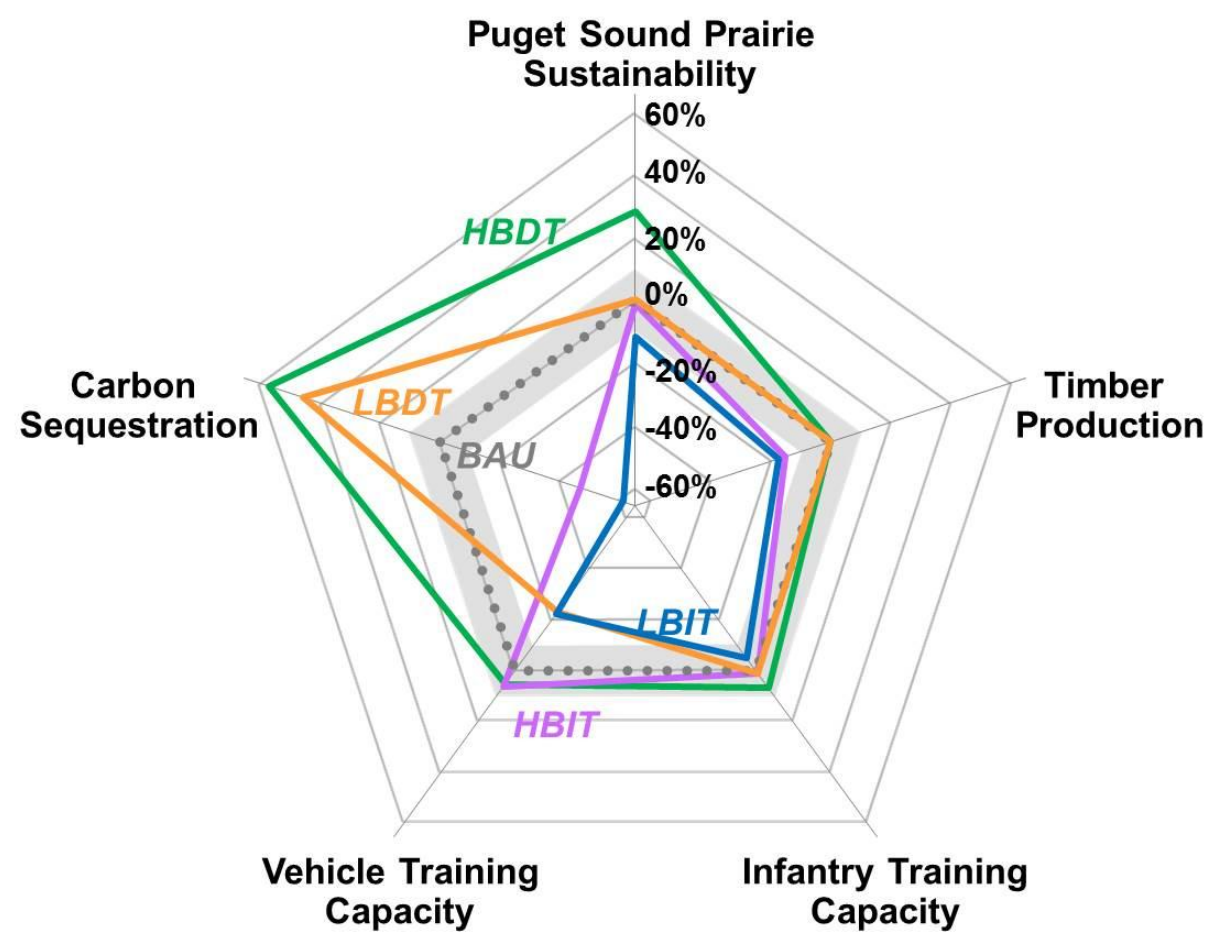

Fig. 4. Percentage change of ecosystem service provision in four alternative scenarios relative to the Business-As-Usual (BAU) scenario for: Puget Sound Prairie sustainability (low-risk in ha), vehicle training capacity (applicable habitat in ha), infantry training capacity (suitable landscape in ha), carbon sequestration (Mg), and timber production (net present value in dollars for 20102030) at Joint Base Lewis-McChord, WA. Alternative scenarios include LBIT (Low BudgetIncreased Training), HBIT (High Budget-Increased Training), HBDT (High Budget-Decreased Training), and LBDT (Low Budget-Decreased Training). Grey shade indicates 10\% variation from BAU.

\subsection{Spatially explicit assessment}

The spatial distribution of ecosystem services highlights important areas and opportunities for addressing management challenges (Fig. 5). We report the relative contribution of training and impact areas to the total provision of each service (Fig. 5A for BAU) using a combined measure of absolute provision and efficiency of provision (i.e., service per unit functional area). Areas with high contribution to infantry and vehicle training capacity are located primarily in the central and east regions, where grasslands are abundant. Some areas of dense forest in these regions provide lower capacity for vehicle training than for infantry (Fig. 5A). The Artillery Impact Area, where Scotch broom cover remains low because of repeated fires triggered during gunnery practices, provides about half of low-risk area sustaining Puget Sound Prairie at JBLM (Fig. 5A). In contrast, grasslands in Training Area 14 are classified as a high-risk area, due primarily to pervasive Scotch broom cover and vehicle training disturbance. Relatively higher carbon sequestration and timber returns overlap in several training areas, mostly covered by forest, in the west and central regions (Fig. 5A). Forest areas in the east region, which show 
relatively lower timber productivity, still serve as an important carbon sink (Fig. 5A).

Aggregating across services, we identified several areas that play major roles in supporting multiple ecosystem services (dark blue in Fig. 5B). Most of these areas are dominated by forest with scattered grassland patches that have minimal training restrictions for protecting candidate species. An exception is Training Area 6, which provides more expansive open space desired for infantry and vehicle training, but with $\sim 50 \%$ of its area restricted. Despite large variations in aggregate provision of some services across scenarios, the relative contributions of each Training Area to each service are generally consistent among all scenarios.

Differences in ecosystem service provision between two extreme scenarios, HBDT and LBIT, reveal areas that can potentially produce large gains with improved management conditions, namely higher funds for conservation or lower training intensity by reallocating budget and training activities among areas. While HBDT provides favorable management conditions in budget and training intensity, LBIT, the most plausible future for JBLM, does not. We illustrate priority management areas in Fig. 5C. Whereas Training Areas 6 and 11 may be managed to improve one service (i.e., vehicle and infantry training capacity, respectively), Training Area 19 is likely to improve both timber production and carbon sequestration. Training Area 4, however, could achieve an increase in three services: infantry training capacity, timber production, and carbon sequestration. Training Area 14, dominated by grasslands, is classified as a high-risk area and harbors only one candidate species. Investment in habitat maintenance could potentially either decrease risk to the area and promote colonization by other species or improve the suitability and provision of unrestricted open area for vehicle training. 


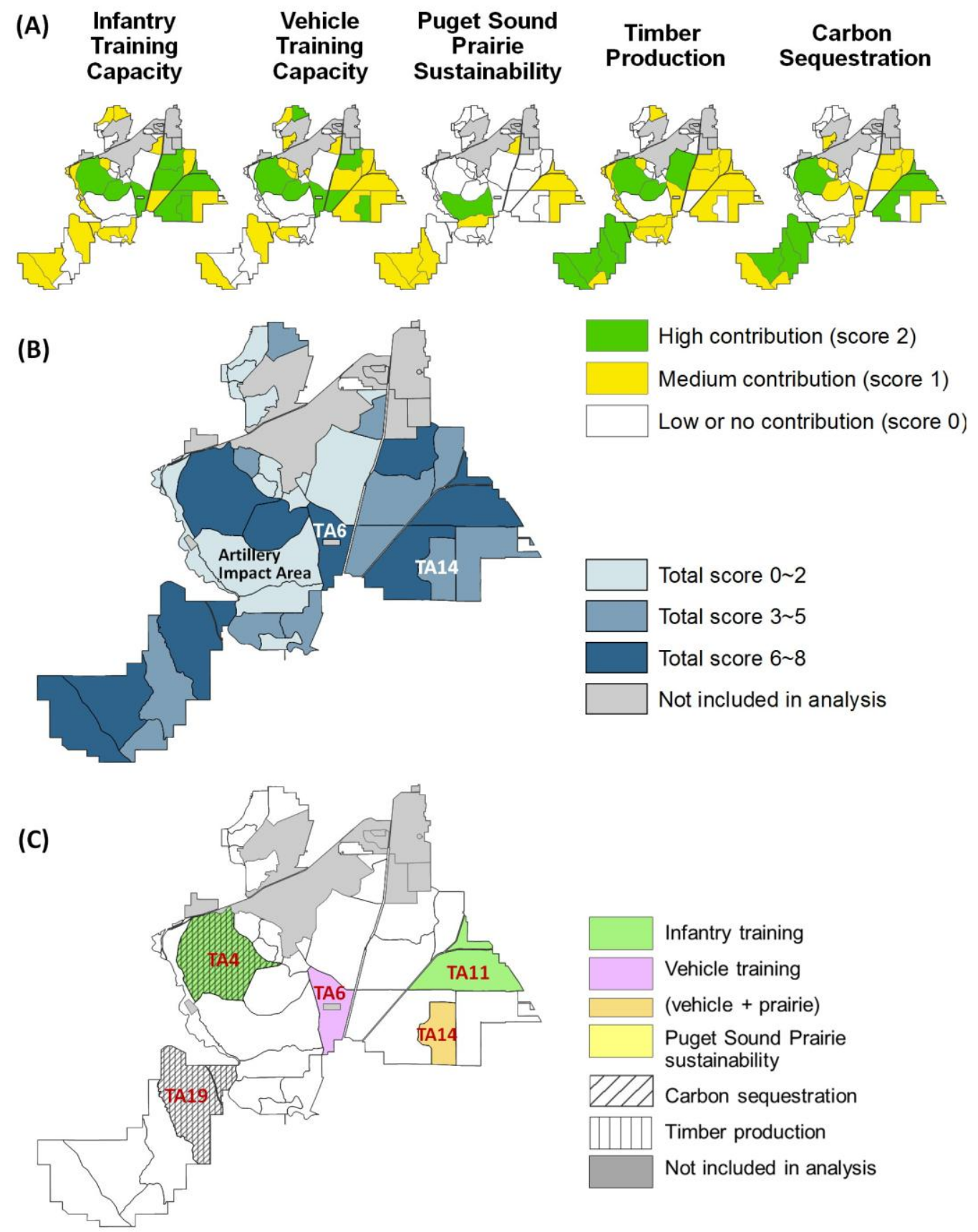

Fig. 5. (A) Relative contribution of Training Areas (TA) and Impact Areas to total ecosystem service provision under the Business-As-Usual (BAU) scenario. Green areas support $>50 \%$ of total ecosystem service provision, yellow areas support an additional $40 \%$, and white areas contribute to the remaining 10\%. (B) Relative contribution of Training/Impact Areas to all five ecosystem services based on the sum of scores. (C) Training/Impact Areas with the largest potential ecosystem service improvements from Low Budget-Increased Training scenario to High Budget-Decreased Training scenario. Selected areas contribute to at least 25\% of the improvement for each service. 


\section{Discussion}

We demonstrate an ecosystem services approach to multiple-use landscape management, codeveloped with a major federal agency. The approach provides new insights into the feasibility and benefits of incorporating ecosystem services into resource management and planning decisions for public agencies and other land-based institutions generally.

Land-use planning often involves evaluating potential ecosystem impacts of different management decisions shaped by factors such as land-use intensity and budget availability. Our study shows how ecosystem services may vary according to policy drivers, in our case training intensity and budget for resource management. We found clear tradeoffs between training intensity and forest-related services and a strong correlation between lowered budget and decreased vehicle training capacity. These findings suggest how management plans may be developed proactively to safeguard priority services when facing changes in budget or land-use intensity. The weak tradeoffs between policy drivers and Puget Sound Prairie sustainability also reveal that impacts imposed by one driver (e.g., increased training intensity) can be mostly offset with complementary change in the other (e.g., higher budget).

Our analysis also shows how considering different ecosystem services may result in different management decisions. If we consider only ecosystem services directly supporting military training capacities and environmental compliance (i.e., Puget Sound Prairie sustainability), budget for resource management plays the dominant role over training intensity for maintaining service provision. However, if indirect links to mission are considered (e.g., potential regulation of greenhouse gas emissions and revenues from timber production), both requirements on training intensity and budget are of equal importance. The expansiveness of ecosystem service analysis is thus crucial to evaluating land-use intensity and budget priorities and justifying requests modifications.

Spatially explicit representations of management options are powerful to inform decisions. Thus, we identified priority areas for sustaining current levels of ecosystem services (Fig. 5B) and areas that might be targeted to improve services provision by shifting management funds to those areas and/or shifting some training activities to other areas at JBLM (Fig. 5C). The spatial distribution of low-risk area sustaining Puget Sound Prairie also reveals a synergy between artillery training and conservation of this rare ecosystem (consistent with Stein et al. 2008, Warren et al. 2007).

The co-development process with stakeholders is an essential component of our ecosystem services approach. This process was enabled by shared interests in improving public land management using integrated approaches, as well as federal funding to support methodology demonstration. Our approach demonstrated three strengths among ecosystem services studies involving stakeholders. First, we engaged stakeholders early in the process to build trust and 
create a mutual understanding of the problem, while some other studies tended to involve stakeholders after producing the results only to enhance the acceptance. Second, we developed a structured, iterative stakeholder process comprising group discussions, in-depth individual interactions, and periodical remote communications. This structure allows for repeated inputs and feedback through different stages of the study to improve the clarity, credibility, and legitimacy of the analyses and acceptance of the results for decision support, without requiring too much time commitment from the stakeholders. We endeavored to accommodate each stakeholder's schedule by balancing group discussions with individual meetings. Third, we communicated the ecosystem services concepts in a local context that resonates with stakeholders' management goals and decision making process. For example, the ecosystem support of biodiversity was defined and modeled as the sustainability of Puget Sound Prairie that dictates the environmental regulations for training activities. We also co-developed and coevaluated the training capacity services, providing unique benefits to the DoD stakeholders.

This stakeholder process requires large time commitment and financial resources, as well as careful selection of the stakeholders to achieve the desired outcomes. This intensive and interactive process is better suited for cohesive groups of stakeholders with some degrees of selforganization and consistent management goals, although stakeholders within the group may have diverse management expertise, approaches, and administrative areas. Public agency stakeholders are such examples as compared to large number of dispersed downstream water users for watershed management. Given the time and financial cost, this co-development approach is also better applied to large scale studies, or local studies with the potential to replicate at large scales. We expect the co-development process to be streamlined in the future with the growing technical capacity of partners, potentially supported by automated data processing tools and online training programs we are currently developing. Other external factors, such as agency-wide policy incentives and central repositories for common datasets, would also facilitate the process.

In sum, our ecosystem services approach integrates transparent ecological models, geographic information system tools, and participatory scenario development and demonstration processes. It has been applied in both developed and developing countries to inform spatial planning of public lands that support multiple uses (e.g., agriculture, mining, recreation, and residential development) in addition to biodiversity conservation (Ruckelshaus et al. 2013, Goldstein et al. 2012, Bhagabati et al. 2014). As government agencies and land-based institutions are progressively incorporating ecosystem services into their management frameworks, this approach has a great potential to fit into broader decision contexts, such as assessment of environmental impacts, evaluation of off-site mitigation options, discussion of conflicting land uses within and among agencies, as well as communication with Congress and the public about ecosystem management objectives. 


\section{Acknowledgements}

We thank D. Clouse, A. Derickson, A. Fox, I. Gruhn, and T. Zuchowski for valuable information and active engagement at Joint Base Lewis-McChord, G. Reub for providing data collected by ENVIRON, as well as A. Kroll, D. Omdal, K. Ripley (Washington Department of Natural Resources) and D. Churchill (University of Washington) for informative discussion about model assumptions. We are grateful to M. Ruckelshaus and E. Rauer at the Natural Capital Project, as well as J. Lawler and the Landscape Ecology and Conservation Lab at the University of Washington for very helpful suggestions. Work was funded by DoD ESTCP project RC-201113. 


\section{References}

Bagstad, K.J., Semmens, D.J. \& Winthrop, R. (2013). Comparing approaches to spatially explicit ecosystem service modeling: a case study from the San Pedro River, Arizona. Ecosystem Services, 5, 40-50.

Bateman, I.J., Harwood, A.R., Mace, G.M., Watson, R.T., Abson, D.J., Andrews, B., Binner, A., Crowe, A., Day, B.H., Dugdale, S., Fezzi, C., Foden, J., Hadley, D., Haines-Young, R., Hulme, M., Kontoleon, A., Lovett, A.A., Munday, P., Pascual, U., Paterson, J., Perino, G., Sen, A., Siriwardena, G., Van Soest, D., \& Termansen, M. (2013). Bringing ecosystem services into economic decision-making: land use in the United Kingdom. Science, 341, 45-50.

BLS (Bureau of Labor Statistics). (2012). Producer price index commodity data: all commodities. 2002-2011. http://www.bls.gov/data/. Viewed 23 July 2012.

Bhagabati, N.K., Ricketts, T., Sulistyawan, T.B.S., Conte, M., Ennaanay, D., Hadian, O., McKenzie, E., Olwero, N., Rosenthal, A., Tallis, H., \& Wolny, S. (2014). Ecosystem services reinforce Sumatran tiger conservation in land use plans. Biol. Conserv., 169, 147-156.

Bossard, C.C., and Rejmanek, M. (1994). Herbivory, growth, seed production, and resprouting of an exotic invasive shrub Cytisus scoparius. Biol. Conserv., 67, 193-200.

Chappell, C.B., \& Crawford, R.C. (1997). Native vegetation of the South Puget Sound prairie landscape. In: Ecology and conservation of the South Puget Sound Prairie landscape (ed. Dunn, P. \& Ewing, K.). The Nature Conservancy, Seattle, pp. 107-124.

Chastain, R. (2008). Annual report to Oak Ridge Institute for Science and Education, US Army, Joint Base Lewis-McCord, Public Works, Environmental Division, Forestry Branch.

Crawford, R.C. \& Hall H. (1997). Changes in the South Puget Sound prairie landscape. In: Ecology and conservation of the South Puget Sound Prairie landscape (ed. Dunn, P. \& Ewing, K.). The Nature Conservancy, Seattle, pp. 11-15.

Cowling, R.M., Egoh, B., Knight, A.T., O'Farrell, P.J., Reyers, B., Rouget, M., Roux, D.J., Welz, A. \& Wilhelm-Rechman, A. (2008). An operational model for mainstreaming ecosystem services for implementation. Proc. Natl. Acad. Sci., 105, 9483-9488.

Daily, G.C., Ouyang, Z., Zheng, H., Li, S., Wang, Y., Feldman, M., Kareiva, P., Polasky, S. \& Ruckelshaus, M. (2013). Securing natural capital and human well-being: innovation and impact in China. Acta Ecologica Sinica, 33, 669-676.

Daily, G.C., Polasky, S., Goldstein, J., Kareiva, P.M., Mooney, H.A., Pejchar, L., Ricketts, T.H., Salzman, J. \& Shallenberger, R. (2009). Ecosystem services in decision making: time to deliver. Front. Ecol. Environ., 7, 21-28.

Daily, G.C., Ruckelshaus, M.H., Ma, S., Eichelberger, B.A., Duggan, J.M. Ghile, Y.B., Kaiser, G.M., McNally, B.W., Ziv, G., Conte, M.N., Dennedy-Frank, P. J., Rauer, E. M. (2015). Enlisting Ecosystem Services: Quantification and Valuation of Ecosystem Services to Inform Base Management. DoD Environmental Security Technology Certification Program (ESTCP), RC-201113. Alexandria, VA: ESTCP. Available at: https://www.serdp-estcp.org/Program-Areas/Resource-Conservation-and-Climate- 
Change/Natural-Resources/Watershed-Processes-and-Management/RC-201113.

Darris, D., Johnson, S., \& Bartow, A. (2012). Plant fact sheet for Roemer's fescue (Festuca roemeri). USDA-Natural Resources Conservation Service, Plant Materials Center. Corvallis, OR: USDA.

De Lange, H.J., Sala, S., Vighi, M., \& Faber, J.H., (2010). Ecological vulnerability in risk assessment- a review and perspectives. Sci. Total Environ., 408, 3871-3879.

DoD (Department of Defense). (2011). Instruction 4715.03. Natural Resources Conservation Program, Washington D.C.

Duggan, J.M., Eichelberger, B.A., Ma, S., Lawler, J.J., \& Ziv, G. (2015). Informing management of rare species with an approach combining scenario modeling and spatially explicit risk assessment. Ecosystem Health and Sustainability, 1, 1-18.

Dunn, P. (1998). Prairie habitat restoration and maintenance on Fort Lewis and within the South Puget Sound prairie landscape. Final Report and Summary of Findings. The Nature Conservancy, Seattle.

Folke, C., Carpenter, S., Walker, B., Scheffer, M., Elmqvist, T., Gunderson, L., \& Holling, C.S., (2004). Regime shifts, resilience, and biodiversity in ecosystem management. Annu. Rev. Ecol. Evol. Syst., 557-581.

Foster, J. (2009). Laminated root rot at Fort Lewis: current status and recommendations for action. Joint Base Lewis-McChord, U.S. Army, Fort Lewis.

Goldman-Benner, R.L., Benitez, S., Boucher T., Calvache, A., Daily, G., Kareiva, P., Kroeger, T., \& Ramos, A. (2012). Water funds and payments for ecosystem services: practice learns from theory and theory can learn from practice. Oryx, 46, 55-63.

Goldstein, J.H., Caldarone G., Duarte, T.K., Ennaanay, D., Hannahs, N., Mendoza, G., Polasky, S., Wolny, S. \& Daily, G.C. (2012). Integrating ecosystem-service tradeoffs into land-use decisions. P. Natl. Acad. Sci. USA, 109, 7565-7570.

Guerry, A.D., Ruckelshaus, M.H., Arkema, K.K., Bernhardt, J.R., Guannel, G., Kim, C.K., Marsik, M., Papenfus, M., Toft, J.E., Verutes, G., Wood, S.A., Beck, M., Chan, F., Chan, K.M.A., Gelfenbaum, G., Gold, B.D., Halpern, B.S., Labiosa, W.B., Lester, S.E., Levin, P.S., McField, M., Pinsky, M.L., Plummer, M., Polasky, S., Ruggiero, P., Sutherland, D.A., Tallis, H., Day, A. \& Spencer, J. 2012. Modeling benefits from nature: using ecosystem services to inform coastal and marine spatial planning. Int. J. Biodivers. Sci. Ecosyst. Serv. Manage., 8, 107-121.

Hansen, E. \& Goheen, E.M. (2000). Phellinus weirii and other native root pathogens as determinants of forest structure and process in western North America. Ann. Rev. Phytopathol., 38, 515-539.

Haynes, R. W., Adams, D. M., Alig, R. J., Ince, P. J., Mills J. R. \& X. Zhou. (2007). The 2005 Renewable Planning Act timber assessment update. Portland, OR: US Department of Agriculture, Forest Service, Pacific Northwest Research Station.

IPCC (Intergovernmental Panel on Climate Change). 2006. 2006 IPCC guidelines for national greenhouse gas inventories. IPCC NGGIP Programme, IPCC-TSU/IGES. Institute for Global Environmental Strategies (IGES), Hayama, Japan. 
Kareiva, P., Tallis, H., Ricketts, T.H., Daily, G.C., Polasky, S. (2011). Natural capital: theory and practice of mapping ecosystem services. Oxford University Press, Oxford.

Keith D.A., Rodríguez J.P., Rodríguez-Clark K.M., Nicholson, E., Aapala, K., Alonso, A., Asmussen, M., Bachman, S., Basset, A., Barrow, E.G., Benson, J.S., Bishop, M.J., Bonifacio, R., Brooks, T.M., Burgman, M.A., Comer, P., Comin, F.A., Essl, F., FaberLangendoen, D., Fairweather, P.G., Holdaway, R.J., Jennings, M., Kingsford, R.T., Lester, R.E., Mac Nally, R., McCarthy, M.A., Moat, J., Oliveira-Miranda, M.A., Pisanu, P., Poulin, B., Regan, T.J., Riecken, U., Spalding, M.D. \& Zambrano-Martinez, S. (2013). Scientific Foundations for an IUCN Red List of Ecosystems. PLOS ONE, 8, e62111.

Kellndorfer, J., Walker, W., LaPoint, E., Bishop, J., Cormier, T., Fiske, G., Hoppus, M., Kirsch, K., and Westfall, J. (2012). NACP Aboveground Biomass and Carbon Baseline Data (NBCD 2000). The Woods Hole Research Center, Falmouth, MA.

Koschke, L., Van der Meulen, S., Frank, S., Schneidergruber, A., Kruse, M., Fürst, C., Neubert, E., Ohnesorge, B., Schröder, C., Müller, F. \& Bastian, O. (2014). Do you have 5 minutes to spare? - The challenges of stakeholder processes in ecosystem services studies. Landscape Online, 37.

Liu, J., Li, S., Ouyang, Z., Tam, C., \& Chen, X. (2008). Ecological and socioeconomic effects of china's policies for ecosystem services. P. Natl. Acad. Sci. USA, 105, 9489-9494.

MA (Millennium Ecosystem Assessment). (2005). Ecosystems and human well-being: synthesis. Island Press, Washington D.C.

McCauley, K. J., \& Cook, S.A. 1980. Phellinus weirii infestation of two mountain hemlock forests in the Oregon Cascades. For. Sci., 26, 23-29.

McKenzie, E., Rosenthal, A., Bernhardt, J., Givetz, E., Kovacs, K., Olwero, N., \& Toft, J. (2012). Developing Scenarios to Assess Ecosystem Service Tradeoffs: Guidance and Case Studies for InVEST Users. World Wildlife Fund, Washington D.C. www.naturalcapitalproject.org/pubs/ScenariosGuide.pdf

McNie, E. C. (2007). Reconciling the supply of scientific information with user demands: an analysis of the problem and review of the literature. Environ. Sci. Policy, 10, 17-38.

Menzel, S., \& Teng, J. (2010). Ecosystem services as a stakeholder-driven concept for conservation science. Conserv. Biol., 24, 907.

Nelson, E. E. \& Hartman, T. (1975). Estimating spread of Poria weirii in a high elevation mixed conifer stand. J. For., 73, 141-42.

Nemec, K. \& Raudsepp-Hearne, C. (2013). The use of geographic information systems to map and assess ecosystem services. Biodivers. Conserv., 22, 1-15.

OMB (Office of Management and Budget). (2011). Circular A-94 Appendix C: discount rates for cost-effectiveness, lease purchase, and related analyses. Washington, DC: OMB.

Pagiola, S. (2008). Payments for environmental services in Costa Rica. Ecol. Econ. 65, 712-724.

Palomo, I., Montes, C., Martín-López, B., Gonzalez, J.A., Garcia-Llorente, M., Alcorlo, P. \& Garcia Mora, M.R. (2014). Incorporating the social-ecological approach in protected areas in the anthropocene. BioScience. doi: 10.1093/biosci/bit033 
Peterson, D.J. \& Prasad, R. (1998). The biology of Canadian weeds. 109. Cytisus scoparius (L.) Link. Can. J. Plant Sci. 78, 497-504.

Polasky, S., Nelson, E., Pennington, D., \& Johnson, K.A. (2011). The impact of land-use change on ecosystem services, biodiversity and returns to landowners: a case study in the state of Minnesota. Environ. Resour. Econ., 48, 219-242.

Quist, M. C., Fay, P. A., Guy, C. S., Knapp, A. K., \& Rubenstein, B. N. (2003). Military training effects on terrestrial and aquatic communities on a grassland military installation. Ecol. Appl., 13, 432-442.

Reed, M.S., Graves, A., Dandy, N., Posthumus, H., Hubacek, K., Morris, J., Prell, C., Quinn, C.H. \& Stringer, L.C. (2009). Who's in and why? A typology of stakeholder analysis methods for natural resource management. J. Environ. Manage., 90, 1933-1949.

Rodríguez, J. P., Rodríguez-Clark, K. M., Baillie, J. E., Ash, N., Benson, J., Boucher, T., Brown, C. et al. (2012). Establishing IUCN Red List Criteria for Threatened Ecosystems. Conserv. Biol., 25, 21-29.

Ruckelshaus, M., McKenzie, E., Tallis, H., Guerry, A., Daily, G., Kareiva, P., Polasky, S., Ricketts, T., Bhagabati, N., Wood, S.A. \& Bernhardt, J. (2013). Notes from the field: lessons learned from using ecosystem services to inform real-world decisions. Ecol. Econ., doi: 10.1016/j.ecolecon.2013.07.009.

Scarlett, L. and J. Boyd. (2013). Ecosystem services and resource management: Institutional issues, challenges, and opportunities in the public sector. Ecol. Econ., doi: 10.1016/j.ecolecon.2013.09.013.

Seppelt, R., Dormann, C.F., Eppink, F.V., Lautenbach, S., \& Schmidt, S. (2011). A quantitative review of ecosystem service studies: approaches, shortcomings and the road ahead. $J$. Appl. Ecol., 48, 630-636.

Stein, B.A., Scott, C., \& Benton, N. (2008). Federal lands and endangered species: the role of military and other federal lands in sustaining biodiversity. BioScience, 58, 339-347.

Sharp, R., H. T. Tallis, T. Ricketts, A. D. Guerry, S. A. Wood, S.A., R. Chaplin-Kramer, E. Nelson, D. Ennaanay, S. Wolny, N. Olwero, K. Vigerstol, D. Pennington, G. Mendoza, J. Aukema, J. Foster, J. Forrest, D. Cameron, K. Arkema, E. Lonsdorf, C. Kennedy, G. Verutes, C. K. Kim, G. Guannel, M. Papenfus, J. Toft, M. Marsik, J. Bernhardt, R. Griffin, K. Glowinski, N. Chaumont, A. Perelman, M. Lacayo, L. Mandle, P. Hamel, and A. L. Vogl. 2014. InVEST user's guide. The Natural Capital Project, Stanford, CA, USA. Available at: http://ncp-dev.stanford.edu/ dataportal/investreleases/documentation/current_release/.

USDA (US Department of Agriculture) Forest Service. (2012). National Forest System Land Management. Federal Register 77(68), 21162-21276. U.S. Government Printing Office, Washington D.C.

USEPA (US Environmental Protection Agency). (2009). Valuing the protection of ecological systems and services. US EPA, EPA-SAB-09-012, Washington D.C.

USFWS (US Fish and Wildlife Service). (2013a). Endangered and threatened wildlife and plants; determination of endangered status for the Taylor's checkerspot butterfly and 
threatened status for the streaked horned lark; final rule. FWS-R1-ES-2012-0080, Washington D.C.

USFWS (US Fish and Wildlife Service). (2013b). Endangered and threatened wildlife and plants; 6-month extension of final determination for the proposed listing and designation of critical habitat for four subspecies of Mazama pocket gopher. FWS-R1-ES-20120088; FWS-R1-ES-2013-0021, Washington, D.C.

Villa, F., Bagstad, K.J., Voigt, B, Johnson, G.W., Portela, R., Honzak, M. \& Batker, D. (2014). A methodology for adaptable and robust ecosystem services assessment. PLOS One, $\mathbf{9}$, e91001.

Warren, S.D., Holbrook S.W., Dale, D.A., Whelan, N.L., Elyn, M., Grimm, W. \& Jentsch, A. (2007). Biodiversity and the heterogeneous disturbance regime on military training lands. Restor. Ecol., 15, 606-612.

Washington Academy of Sciences. (2013). Opportunities for addressing laminated root rot caused by Phellinus sulphuracens in Washington's forests. Olympia, WA: Washington State Academy of Sciences and Washington State Department of Natural Resources.

Wheeler, C. T., Helgerson, O. T., Perry, D. A., \& Gordon, J. C. (1987). Nitrogen fixation and biomass accumulation in plant communities dominated by Cytisus scoparius $\mathrm{L}$. in Oregon and Scotland. J. Appl. Ecol., 24, 231-37.

Whitecotton, R. C., David, M. B., Darmody, R. G., \& Price, D. L. (2000). Impact of foot traffic from military training on soil and vegetation properties. Environ. Manage., 26, 697-706.

WSDoR (Washington State Department of Revenue). (2012). Stumpage value determination tables (1973-2012). Olympia, WA: WSDoR.

Zheng, H., Robinson, B.E., Liang, Y., Polasky, S., Ma, D.C., Wang, F.C., Ruckelshaus, R., Ouyang, Z.Y., \& Daily, G.C. (2013). Benefits, costs, and livelihood implications of a regional payment for ecosystem service program. P. Natl. Acad. Sci. USA, 110, 1668116686. 